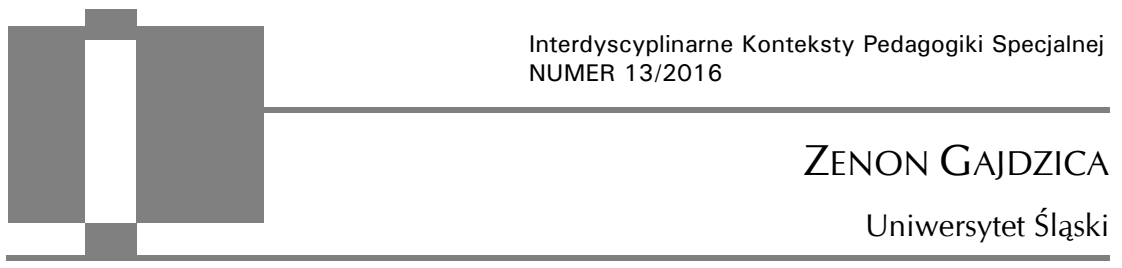

\title{
Uchwycić indywidualność, czyli o wybranych aspektach studium przypadku osoby z niepełnosprawnością
}

\begin{abstract}
AвstrACT: Zenon Gajdzica, Uchwycić indywidualność, czyli o wybranych aspektach studium przypadku osoby z niepetnosprawnościa [To capture individuality - on some selected aspects of the case study of a person with disability]. Interdyscyplinarne Konteksty Pedagogiki Specjalnej, nr 13, Poznań 2016. Pp. 49-66. Adam Mickiewicz University Press. ISSN 2300-391X
\end{abstract}

The starting point for this study is the thesis that disability multidimensionally determines human functioning, enhances human uniqueness and is favourable for emphasizing a person's individuality. This inspires to use a study of an individual case as a method not only of its cognition and description but also its understanding. The method also makes it easier to construct individual concepts of functioning of a person with disability in the jungle of many biological, psychological and social determinants. Moreover, for the researcher - the method may become a valuable source of experience and an inspiration for his/her own (not only scientific) development. To provide justification for this thesis, a survey of case studies is made, with special focus on the authorial typology of didactic (educational) goals - the aims which are usually underrated in scientific works. What follows are the possible typologies of the discussed method and the author's suggestions concerning the construction of a case study of a disabled person. The text is completed with final conclusions

KEY WORDS: case study, disability, educational dimension of case study, individuality 


\section{Wprowadzenie}

Punktem wyjścia opracowania jest teza, że niepełnosprawność wielowymiarowo warunkuje funkcjonowanie człowieka, wzmacnia jego unikatowość i sprzyja akcentowaniu jego indywidualności. To zaś stanowi inspirację nie tylko do stosowania studium indywidualnego przypadku jako metody poznania i deskrypcji jego codzienności, ale również jego zrozumienia. Metoda ta umożliwia konstrukcję jednostkowych koncepcji funkcjonowania osoby obarczonej niepełnosprawnością $\mathrm{w}$ gąszczu wielu biologicznych, psychologicznych i społecznych uwarunkowań. Ponadto może stanowić wartościowe źródło doświadczenia dla samego badacza, tym samym być dla niego inspiracją dla własnego - nie tylko naukowego rozwoju.

Chociaż studium indywidualnych przypadków jest metodą powszechnie stosowaną $w$ naukach społecznych i humanistycznych, to jego istota nierzadko sprowadzana jest jedynie do zadań egzemplifikujących zebranych uprzednio - przy pomocy innych metod - danych. Tymczasem to tylko jedna z możliwych funkcji tej metody i trudno uznać ją za wiodącą. Już we wstępie pragnę zwrócić uwagę na jej wartość na dwóch płaszczyznach. Pierwsza dotyczy możliwości kompleksowego i holistycznego opisu uwzględniającego wiele zmiennych. To przede wszystkim wartość poznawcza. Służy ona zidentyfikowaniu tego, co trudno dostrzegalne, nierzadko stanowiące imponderabilia i epifonemy tego, co przejrzyste i mierzalne innymi metodami. Druga - to wartość ukierunkowana nie tyle na wyjaśnienie co na zrozumienie ${ }^{1}$. Przy czym zrozumienie to - mimo podkreślanych wad studium przypadku w zakresie możliwości jakiegokolwiek uogólniania ${ }^{2}$ - umożliwia także (przynajmniej w niektórych obszarach) rozumienie innych przypadków. Po-

${ }^{1} \mathrm{~K}$. Konecki, Studia z metodologii badań jakościowych. Teoria ugruntowana, Wydawnictwo Naukowe PWN, Warszawa 2000, s. 127

2 B. Flyvbjerg, Pięć mitów o badaniach typu studium przypadki, „Studia Socjologiczne" 2005, nr 2, s. 42. 
nadto niesie jeszcze inną wartość - dydaktyczną, ponieważ poznanie i zrozumienie Innego człowieka tworzy siebie w relacji z nim, to zaś ułatwia zrozumienie jego i siebie ${ }^{3}$. Warto podkreślić wagę tej opinii w kontekście inności/obcości sprzyjającej odrzucaniu i ekskluzji osób z niepełnosprawnością lub inną odmiennością. Naturalnie wartość ta nie może zostać ograniczona (chociaż wykracza to poza intencję cytowanego autora) do przypadku osoby, może dotyczyć także innych obiektów czy zjawisk określanych w badaniach mianem indywidualnego przypadku.

Motywując przywołaną we wstępie tezę, dokonuję przeglądu celów studium przypadku, ze szczególnym uwzględnieniem autorskiej typologii celów dydaktycznych (edukacyjnych) - zwykle deprecjonowanych $\mathrm{w}$ opracowaniach naukowych. W dalszej kolejności przedstawiam możliwe typologie omawianej metody oraz autorskie propozycje konstrukcji studium przypadku osoby z niepełnosprawnością.

\section{Cele stosowania studium indywidualnego przypadku}

Praktycznie każde szersze opracowanie na temat studium indywidualnego przypadku zawiera określenie jego celów wykorzystania. Przy czym większość przywoływanych niżej autorów podkreśla swoistość omawianej metody i jej przydatność w sprecyzowanych założeniach eksploracyjnych. Uogólniając, cele można podzielić na trzy grupy:

- praktyczne - udzielić adekwatnej pomocy,

- naukowe - poznać i zrozumieć,

- dydaktyczne - nauczyć się czegoś4.

Tradycja stosowania studium przypadku, zakorzeniona $\mathrm{w}$ badaniach praktycznych ukierunkowanych na realizację określonych

${ }^{3}$ J. Szczepański, Sprawy ludzkie, Czytelnik, Warszawa 1980, s. 82-83.

${ }^{4} \mathrm{~K}$. Baranowicz, Studium indywidualnego przypadku w pracy pedagoga specjalnego, [w:] Pedagogika specjalna w reformowanym ustroju edukacyjnym, red. Z. Palak,, UMCS, Lublin 2001, s. 116. 
działań (np. wsparcia) gruntuje i uzasadnia jego cele aplikacyjne ${ }^{5}$. Do podstawowych celów w tym zakresie należy dostarczenie praktycznych rozwiązań określonego rodzaju problemów, np. organizacyjnych, związanych z ewaluacją interwencji społecznych ${ }^{6}$. Często stają się one wstępem do realizacji celów naukowych, ponieważ ich podstawą jest poznanie przypadku wraz z otaczającym go kontekstem.

Celom naukowym autorzy charakterystyk studium poświęcają najwięcej miejsca. Są one formułowane w różny sposób. Część $\mathrm{z}$ nich ukierunkowana jest na opis, np.:

- ukazanie funkcjonowania osób badanych lub określonej instytucji opieki, wychowania czy kształcenia ${ }^{7}$,

- dokładny opis badanego (osoby, obiektu) z możliwie różnych stron i z uwzględnieniem rozmaitych jego aspektów ${ }^{8}$,

- celem tej metody badawczej jest dogłębne przestudiowanie i szczegółowe opisanie konkretnego przypadku lub kilku przypadków ${ }^{9}$.

Kolejne cele akcentują dostarczanie wiedzy, np.:

- dostarczanie wiedzy kontekstowej,

- dostarczanie wiedzy prognostycznej (np. hipotez możliwych do weryfikowania na większej grupie badanej),

- dostarczanie wiedzy uogólniającej (falsyfikującej przypadek czarnego łabędzia) ${ }^{10}$,

${ }^{5}$ A.M. Hocutt, K.M. Fowler, Case Study Research: An Overview, [w:] Qualitative Research Methods in Special Education, red. J. Paul, J. Kleinhammer-Tramill, K. Fowler, Love Publishing Company, Denver - London - Sydney 2009, s. 53-54.

${ }^{6}$ Za: M. Strumińska-Kutra, I. Koładkiewicz, Studium przypadku, [w:] Badania jakościowe. Metody i narzędzia, t. 2, red. D. Jemielniak, Wydawnictwo Naukowe PWN, Warszawa 2012, s. 4.

${ }^{7}$ M. Łobocki, Wprowadzenie do metodologii badań pedagogicznych, Impuls, Kraków 1999, s. 246.

8 T. Pilch, T. Bauman, Zasady badań pedagogicznych. Strategie ilościowe i jakościowe, Żak, Warszawa 1998, s. 298.

${ }^{9} \mathrm{Za}$ : D. Kubinowski, Jakościowe badania pedagogiczne. Filozofia - metodyka - ewaluacja, UMCS, Lublin 2010, s. 172.

10 B. Flyvbjerg, op. cit., s. 42-55. 
- uzyskanie wiedzy o jednostkach, grupach, organizacjach, zjawiskach (społecznych, politycznych) ${ }^{11}$.

Opis przypadku oraz uzyskanie określonej wiedzy na jego temat może służyć jego wyjaśnienia i zrozumieniu, co obrazuje kolejna grupa celów, np.

- studium przypadku to schemat, który zmierza do opisania i wyjaśnienia przebiegu, obrazu zjawiska ogólnego umiejscowionego w jakiejś osobie, grupie czy instytucji12,

- $\mathrm{w}$ metodzie studium przypadku celem jest przede wszystkim całościowy opis i zrozumienie przypadku wraz z otaczającym go kontekstem ${ }^{13}$,

- konkretny przypadek wykorzystywany w dyscyplinie zarządzania służy do opisu, wyjaśniania oraz najczęściej uogólniania pewnego szczególnego zjawiska będącego w polu zainteresowań badacza ${ }^{14}$.

Wiedza i zrozumienie stanowią wstęp do grupy celów ukierunkowanych na tworzenie teorii, np.:

- studium przypadku to schemat badania jakościowego, które zmierza do stworzenia jednostkowej teorii zjawiska ogólnego ${ }^{15}$,

- użycie uzyskanych wyników do stworzenia abstrakcyjnych pojęć ogólnych pozwalających na opis i wyjaśnienie badanego zjawiska,

- stworzenie teorii pozwalającej na wyjaśnienie i przewidywanie rzeczywistości społecznej w pewnym obszarze,

${ }^{11}$ R.K. Yin, Studium przypadku w badaniach naukowych. Projektowanie $i$ metody, Wydawnictwo Uniwersytetu Jagiellońskiego, Kraków 2015, s. 36-37.

12 K. Rubacha, Metodologia badań nad edukacja, Wydawnictwo Akademickie i Profesjonalne, Warszawa 2008, s. 329.

13 Za: M. Strumińska-Kutra, I. Koładkiewicz, op. cit., s. 4.

${ }^{14}$ K. Obłój, A. Wąsowska, Studium przypadku, [w:] Metody badawcze w zarządzaniu humanistycznym, red. M. Kostera, Wydawnictwo Akademickie Sedno, Warszawa 2015, s. 51.

${ }^{15} \mathrm{~K}$. Konarzewski, Jak uprawiać badania oświatowe. Metodologia praktyczna, WSiP, Warszawa 2000. s. 78. 
- modyfikacja lub uzupełnienie istniejących teorii,

- odniesienie do szerszej kategorii podobnych zjawisk ${ }^{16}$.

Cele studium przypadku można zatem uporządkować w pewne kontinuum: opis - poznanie (zdobycie wiedzy) - wyjaśnienie (interpretacja) - zrozumienie - zbudowanie teorii (falsyfikacja, uzupełnienie istniejącej teorii). Zakładając liniowy tok myślenia, nadrzędnymi celami stosowania studium przypadku jest zrozumienie i tworzenie teorii. Przyjęcie tych celów jako nadrzędnych nie tylko nie deprecjonuje poprzednich, ale ukazuje je jako etapowe i konieczne w realizacji celów głównych.

Wartość dydaktyczną omawianej metody można rozpatrywać przynajmniej w czterech zakresach:

- nabywania kompetencji badawczych,

- zdobywania materiałów do dyskusji i analiz przydatnych w rozszerzaniu wiedzy o świecie,

- poznawania określonego wycinka rzeczywistości społecznej,

- poznawania siebie.

W praktyce trudno całkowicie je rozdzielić ostrą granicą, także w zakresie związków z innymi - praktycznymi i naukowymi celami.

Kwestie dydaktyczne w naukowych opracowaniach omawiających studium przypadku zwykle pozostają na marginesie rozważań autorów. Cele te nawet bywają deprecjonowane i traktowane (w moim przekonaniu często, aczkolwiek nie zawsze niesłusznie) jako całkowicie rozbieżne z celami naukowymi. Przykładem tej deprecjacji jest przekonanie, że studium przypadku wykorzystywane w celach edukacyjnych nie musi zawierać pełnej ani poprawnej interpretacji rzeczywistych faktów ${ }^{17}$, co w mojej opinii trudno zaakceptować.

Poniżej podejmuję próbę rozpatrzenia celów dydaktycznych, porządkując je zgodnie z przywołanymi płaszczyznami.

1. Nabywanie kompetencji badawczych to zwykle cel poboczny prowadzonych analiz naukowych. Naturalnie omawiane studium,

16 Za: M. Strumińska-Kutra, I. Koładkiewicz, op. cit., s. 4.

17 R.K. Yin, op. cit., s. 37. 
podobnie jak każda inna metoda, może być wykorzystywane wyłącznie do doskonalenia warsztatu badawczego, ale trudno ją w tym zakresie uznać za metodę całkowicie przeciętną. Jej mocną stroną $\mathrm{w}$ realizacji tego celu jest konieczność wykorzystywania wielu technik badawczych, gromadzenie kompleksowego i spójnego materiału uwzględniającego kontekstualność, co z kolei generuje opisy wymagające uchwycenie i uporządkowanie wielu zmiennych $^{18}$. Stosowanie tej metody uczy dostrzegania subtelnych, trudno uchwytnych (w badaniach na dużych grupach) cech, własności, procesów oraz precyzowanie ich znaczenia dla rozwoju, przebiegu zdarzeń czy kreowania się stanów badanego obiektu. Ponadto często wymaga zmiany perspektywy badawczej (punktu widzenia). Wszak jej istota jest spojrzenie na badany obiekt $\mathrm{w}$ taki sposób, by uzyskany opis przyjął postać nie tyle dagerotypu, co wielowymiarowego hologramu ukazującego przypadek $\mathrm{w}$ przestrzeni społecznej. To zaś może narażać badacza (w przeciwieństwie do metod jasno osadzonych w konkretnej perspektywie badawczej) na niebezpieczeństwa eklektyzmu i mieszania paradygmatów badawczych. Opanowanie umiejętności unikania niewspółmierności metodologicznych, obserwacyjnych, ilościowych, językowych, ontologicznych $^{19} \mathrm{w}$ jednym projekcie badawczym stanowi ważny kapitał do dalszych badań naukowych. Konieczność złożonego oglądu stawia zatem badacza $\mathrm{w}$ rożnych perspektywach i sprzyja umiejętnościom ich racjonalnego oraz poprawnego metodologicznie łączenia. Innym niebezpieczeństwem dla badacza wykorzystującego studium jest zagadnienie poprawnego opisu danych i konstytuowania na nich wniosków uprawniających do uogólniania i prognozowania związków przyczynowo-skutkowych czy falsyfikowania uznanych teorii. Problem ten został $\mathrm{w}$ literaturze przedmiotu obarczony wieloma mitami $^{20}$. Zrozumienie $w$ tym zakresie ograniczeń omawianej me-

18 B. Pawłowska, Studium przypadku, [w:] Słownik socjologii jakościowej, red. K. Konecki, P. Chomczyński, Difin, Warszawa 2012, s. 268.

19 Zob. P. Feyerabend, Jak być dobrym empirysta, PWN, Warszawa 1979, s. 62-63.

20 B. Flyvbjerg, op. cit. 
tody niesie ze sobą ważne umiejętności, szczególnie dla badaczy korzystających z metod interpretatywnych. Znaczenie dla rozwoju podmiotu ma także sam opis studium. Może on przyjmować różne formy w zależności od przyjętych założeń ontologicznych i epistemologicznych oraz koncepcji metodologicznych (dokładniej opisuję to zagadnienie $\mathrm{w}$ dalszej części artykułu). Jedną $\mathrm{z}$ nich jest forma deskrypcji przyjmująca postać opowieści zakorzenionej w danych empirycznych. Maria Janion stawia tezę, że podstawą humanistyki jest opowieść. Pisze: „nie wystarczy coś zobaczyć, przeżyć, lub nawet pojąć. Trzeba jeszcze umieć to opowiedzieć" 21. Tym samym nadaje opowieściom wyjątkowy charakter. Są one czymś więcej niż poznaniem i zrozumieniem. Opowiadający przenosi zdarzenia w subiektywny wymiar, nadaje im określone sensy, przekazuje je słuchającemu - tworzy historię. Natomiast Jerome Bruner podkreśla, że narracje są najbardziej naturalnym i najbardziej pierwotnym sposobem organizacji zdobytej wiedzy o świecie. Zawierają one sekwencję zdarzeń będących nośnikiem znaczeń, a zarazem zawierają implikowaną im ocenę 22 . Dlatego m.in. metodę tę należy uznać za wartościową w kreowaniu warsztatu badawczego i rozumienia otaczającego świata.

2. Innym możliwym celem edukacyjnym metody indywidualnych przypadków jest zdobywanie informacji służących jako punkt wyjścia do dyskusji - wyznaczania ram debat osób uczących się. Studium przypadku w tym ujęciu jest więc narzędziem edukacyjnym ${ }^{23}$. Spoglądając na nią z punktu widzenia nauk o wychowaniu, doceniamy jej wartość w zakresie indywidualnej deskrypcji konkretnych losów ludzkich stanowiących jednostkowe przypadki. Wiedza o nich służy sprowokowaniu dyskusji nad uwarunkowaniami zdiagnozowanego stanu. Mogą one być immanentną częścią poznania. Wówczas podmiot uczący się dokonuje zestawienia in-

${ }^{21}$ M. Janion, Niesamowita Stowiańszczyzna, Wydawnictwo Literackie, Kraków 2006, s. 9.

22 J. Bruner, Kultura edukacji, Universitas, Kraków 2006, s. 170-171.

23 R.K. Yin, op. cit., s. 37. 
formacji i wychodząc poza nie (np. w toku dyskusji grupowej w trakcie zajęć lub indywidualnego oglądu w toku pracy własnej), formułuje wnioski ${ }^{24}$. Następnie na ich podstawie tworzy program wychowawczy, edukacyjny, terapeutyczny itd. Naturalnie w tym ujęciu cele edukacyjne łączyć mogą się z celami praktycznymi, ponieważ program ten może zostać wykorzystany w praktyce. Niemniej jednak jeżeli celem działań jest nabywanie kompetencji praktycznych, to właśnie cel ten pozostaje wiodący. Jeżeli indywidualny przypadek w punkcie wyjścia procesu badawczo-edukacyjnego traktowany jest jako problem, studium takie można zaliczyć w poczet metod problemowych. W kształceniu zawodowym to metoda często stosowana wśród lekarzy czy prawników, gdzie stanowi sposób kształtowania profesjonalnego osądu przez interpretację przypadku i jego kontekstu - czyli całej sytuacji, w której się znajduje ${ }^{25}$. Warto zwrócić uwagę, że proces postępowania badawczego $\mathrm{w}$ ramach studium (gromadzenie informacji, ich integrowanie, także z informacjami już posiadanymi przez podmiot, interpretowanie, stawianie hipotez o związkach i uwarunkowaniach, poszukiwanie rozwiązań) wpisuje się w klasyczną metodę problemową.

Innym walorem takich działań jest dostarczenie podmiotowi uczącemu się narzędzi analizy rzeczywistości. Opracowanie studium określonego przypadku może tworzyć coś w rodzaju schematu poznania, ten zaś przyswojony i zrozumiany przez uczących się może stanowić narzędzie poznania innych, analogicznych lub zbliżonych, przypadków. Naturalnie tak rozumiane narzędzie obarczone jest w naukach o wychowaniu (szczególnie osób z niepełnosprawnościami) możliwymi błędami ekwiwalencji, ale ich rozpoznawanie oraz uwzględnianie może być także jednym z elementów procesu edukacyjnego. To zaś powinno uwrażliwiać (zwłaszcza w omawianym obszarze) na indywidualność każdej badanej osoby czy innego obiektu.

24 Por. W. Okoń, Wprowadzenie do dydaktyki ogólnej, Wydawnictwo Żak, Warszawa 1995, s. 263.

${ }^{25}$ K. Baranowicz, op. cit., s. 121. 
3. Poznawanie określonego wycinka rzeczywistości społecznej i przedstawianie go (np. w formie narracji biografii czy złożonego problemu) określonemu audytorium - studentom, uczniom czy innej grupie społecznej - może spełniać funkcję edukacyjną. W przypad$\mathrm{ku}$ studium osoby z niepełnosprawnością zapewne umożliwia poznanie jej rzeczywistości społecznej, sposobu postrzegania świata, zidentyfikowaniu barier, z jakimi się spotyka, uwarunkowań sukcesów czy znoszeniu stereotypów i uprzedzeń. Dla wielu osób wiedza „zawarta w przypadku" stanowi historię lepiej oddziałującą na wyobraźnie i kreującą nastawienie aniżeli zbiór danych statystycznych czy relacji dotyczących całych grup, ponieważ daje wgląd w szczególną, jednostokową sytuację osoby z niepełnosprawnością ${ }^{26}$.

4. Studium indywidualnego przypadku osoby z niepełnosprawnością (zapewne także innych obiektów badań), szczególnie w wymiarze jej zrozumienia niesie także wartość dydaktyczną w zakresie samorozwoju - kreowania siebie. Znaczenie zrozumienia Innego dla własnego rozwoju w przywołanym już eseju Innych człowiek podkreśla Jan Szczepański, pisząc: „Inny jest przede wszystkim konieczny, bym uświadomił sobie własne istnienie i własne cechy. [...] Inny jest lustrem, w którym się sprawdzam i w którym odkrywam swoją identyczność. [...] Inny jest także wzorem, według którego kształtuję siebie"27. Nie wgłębiając się w dyskusję nad zakresem i meritum procesów samorozwoju, zakładam, że podstawą tworzenia siebie i własnej drogi życiowej jest aktywność autokreacyjna. Przyjmuję za Marią Dudzikową, że rozbieżność między Ja idealnym i Ja realnym w określonych warunkach jest jej podstawą ${ }^{28}$. Natomiast jej istota jest

inicjowanie i realizowanie przez jednostkę zadań w celu osiągania własnej osobowości i zachowaniach zmian zgodnych z pożądaniami przez jednostkę standardami (Ja idealne). Autokreacja obejmuje więc dążenia

26 Ibidem s. 122.

27 J. Szczepański, op. cit., s. 52-53.

${ }^{28}$ M. Dudzikowa, Pomyśl siebie. Minieseje dla wychowawców klasy, GWP, Gdańsk 2007, s. 288. 
jednostki do samookreślania się będącego w relacji ze stadium rozwojowym, w którym się znajduje (patrz prace J. Piageta, L. Kohlberga, E. Eriksona) i w powiązaniu z całością jej dążeń życiowych, wynikającej z przyjętej przez nią ogólnej koncepcji świata i własnej w nim miejsca oraz realizowanej koncepcji własnej osoby, samodzielne kierowanie sobą i swoim rozwojem ${ }^{29}$.

Studium indywidualnego przypadku osoby $\mathrm{z}$ niepełnosprawnością dla podmiotu uczącego się może wynieść decentralistyczny punkt odniesienia $w$ procesach autokreacyjnych. Na podstawie informacji zawartych w studium, niepełnosprawność i jej konsekwencje w życiu codziennym tworzą swoiste zwierciadło dla ja realnego i ukazują szeroki wachlarz możliwości, jakże często niedostrzegany przez osoby określane mianem pełnosprawnych. Informacje te mogą być także swoistym czynnikiem motywującym do działalności autokreacyjnej oraz poszukiwania własnych, oryginalnych dróg rozwoju i aktywności społecznej.

\section{Typy studium przypadku}

Istnieje wiele możliwych typologii studium przypadku. Kryteria podziałów dotyczą omówionych wcześniej celów, ponadto także doboru przypadków, ich liczby, osadzenia w paradygmacie badawczym i w związku z tym obranej koncepcji prowadzenia badań czy tylko samego opisu badań, a także obiektu badań ${ }^{30}$.

Jednym z najprostszych, a zarazem często stosowanych kryteriów na poziomie wstępnego oglądu opisywanej metody jest kryterium typu obiektu. Przypadek lub zbiór przypadków zawsze pozostaje $\mathrm{w}$ istotnej relacji $\mathrm{z}$ zgromadzonymi $\mathrm{i}$ analizowanymi danymi oraz celami badań - w związku z tym kryterium to często krzyżuje się z innymi. Przypadkiem może być osoba, organizacja, kultura

${ }^{29}$ Ibidem, s. 288.

${ }^{30}$ Zob. m.in.: K. Baranowicz, op. cit.; B. Flyvbjerg, op. cit.; B. Pawłowska, op. cit.; M. Strumińska-Kutra, I. Koładkiewicz, op. cit.; R.K. Yin, op. cit. 
organizacyjna, środowisko społeczne ${ }^{31}$. Jak zauważa Krzysztof Konarzewski ${ }^{32}$, „przypadek” to słowo dwuznaczne. W podstawowym znaczeniu nazywa pewną przypadłość (chorobę, rolę społeczną, talent) przynależną do konkretnej osoby lub grupy osób. We wtórnym znaczeniu - zdaniem cytowanego autora - to sam obiekt dotknięty tą przypadłością. W tym znaczeniu przypadkiem nazywa się zatem także każdą osobę/grupę osób wybraną lub wylosowaną do badania. Przypadkiem mogą też być konkretne organizacje, w obrębie których przebiegają interesujące badacza zjawiska. Uogólniając - obiektem studium przypadku mogą być osoby, grupy ludzi, organizacje, ale także interesujące badacza procesy, stany, własności im przynależne, a nawet przestrzenie zakreślające ramy odbywania się/funkcjonowania sprecyzowanej grupy podmiotów. Założenie to pozwala na wyróżnienie dwóch grup przypadków: materialnych i niematerialnych. Przy czym te drugie zwykle stanowią wyodrębnione zjawisko (np. kultura szkoły) przynależne określonemu materialnemu obiektowi (szkole jako instytucji i jej poszczególnym elementom). Ważne, by obiekt badań można było względnie jednoznacznie wyróżnić jako pewnego rodzaju system, a obserwowane $\mathrm{w}$ ramach jego działania (czy zachodzące procesu) powinny przebiegać według dających się zrekonstruować wzorców. Wyraźne granice oraz wzory zachowań są kluczowymi elementami pozwalającymi zrozumieć dany przypadek ${ }^{33}$.

\section{Studium przypadku osoby z niepełnosprawnością - możliwe struktury koncepcji badawczej}

Studium przypadku okazuje się bezcenne, gdy interesujące badacza zjawisko jest rzadkie ${ }^{34}$. Konstatacja ta nie umniejsza wartości

\footnotetext{
31 B. Pawłowska, op. cit., s. 269.

32 K. Konarzewski, op. cit., s. 78.

${ }^{33}$ K. Konecki, op. cit., s. 126.

${ }^{34}$ K. Konarzewski, op. cit., s. 79.
} 
studium przypadku przeciętnego - egzemplifikującego $\mathrm{w}$ formie reprezentacji sprecyzowaną grupę, zwłaszcza jeśli sprzyja odkryciu/skonstruowaniu modelu czy koncepcji służącej wyjaśnieniu zebranych danych w badaniach na większych grupach. Warto jednak wspomnieć, że przypadki same w sobie zawierają założenie oryginalności, często także unikatowości wymykającej się ogólnym, znanym już regułom. Badacze przypadków poszukują zatem w danym przypadku zarówno tego, co wyjątkowe, jak i tego, co przeciętne ${ }^{35}$. M.in. dlatego metoda ta stanowi szczególną wartość $\mathrm{w}$ badaniach osób z niepełnosprawnością (także ich codzienności $\mathrm{w}$ relacji z innymi obiektami), jakże chętnie określanych w literaturze jako Innych. Poniżej prezentuję trzy możliwe koncepcje strukturalizacji studium zakorzenione w założeniach:

- ontologicznych (związanych z wiodącą teorią),

- epistemologicznych (nieco upraszczającą skojarzonych tu głównie z technikami poznania oraz źródłami informacji),

- metodologicznych (ukonstytuowanych w związku z postawionymi problemami badawczymi).

W zależności od przyjętej koncepcji wstępnej, inność nie musi dotyczyć wyłącznie ograniczeń funkcjonalnych, a może wiązać się ze zdolnościami (czy innymi cechami) oraz szerszym kontekstem, w którym osoba $z$ niepełnosprawnością funkcjonuje. W tym ujęciu indywidualność można traktować jako mechanizm życiowy spełniający istotne funkcje w życiu jednostek i całych grup społecznych ${ }^{36}$ stanowiący nadbudowę integrującą funkcjonowanie człowieka na wielu płaszczyznach warunkowanych zespołami posiadanych przez niego cech. Przywołany wyżej autor wyróżnia trzy zespoły cech, które w moim przekonaniu, mogą stanowić jeden z wyznaczników porządkowania koncepcji badawczej studium przypadku, są to:

35 R.E. Stake, Jakościowe studium przypadku, [w:] Metody badań jakościowych, t. 2, red. N.K. Denzin, Y.S. Lincoln, Wydawnictwo Naukowe PWN, Warszawa 2009, s. 629 .

36 J. Szczepański, O indywidualności, Instytut Wydawniczy Związków Zawodowych, Warszawa 1988, s. 8. 
- cechy wspólne wszystkim ludziom lub wspólne większym lub mniejszym zbiorowościom,

- cechy podobne u wielu osób,

- cechy charakterystyczne tylko dla jednej osoby - stanowiące podstawę jej indywidualności ${ }^{37}$.

Koncepcja ta, opracowana i rozbudowana na gruncie pedagogiki specjalnej przez Aleksandra Hulka ${ }^{38}$, może stanowić gotowy schemat studium przypadku osoby z niepełnosprawnością. Umożliwia dostrzeżenie i opisanie tego, co stanowi o unikatowości (w aspekcie tego co definiowane społecznie jako przeciętne), z jednoczesnym osadzeniem w tym co wspólne lub częściowo zbieżne (zarówno w zakresie cech jako i okoliczności funkcjonowania) podmiotu stanowiącego przypadek. Pozwala zatem na osadzenie unikatowości w przeciętności i w związku z tym na jej zinterpretowanie oraz zrozumienie m.in. z perspektywy kultury dominującej, czyli kultury pełnosprawności lub przeciętności. Przykład ten obrazuje konstrukcję badawczą studium wyprowadzoną z określonej teorii, umożliwia zatem także spójne określenie założeń ontologicznych.

Inną możliwą konstrukcję odnajdujemy w odzwierciedleniu zestawu technik badawczych, a nawet narzędzi służących zbieraniu danych i źródeł informacji. Konstrukt taki zakłada deskrypcję ukonstytuowaną na sposobach gromadzenia danych, czyli opisie wyników nie tyle w oparciu o istotę przypadku, o ile o techniki i źródła jej poznania. Sztandarową ilustrację takiej koncepcji stanowi przypadek realizacji obowiązku szkolnego w klasie ogólnodostępnej przez ucznia z niepełnosprawnością. Jego istotą jest zebranie danych techniką wywiadu (np. z wychowawca, innymi nauczycielami, pedagogiem szkolnym, rodzicami), obserwacji, analizy wytworów (jego oraz innych uczniów), dokumentów (np. dziennika,

37 Ibidem, s. 7.

38 A. Hulek, Wspólne i swoiste zagadnienia w rewalidacji różnych grup osób z odchyleniami od normy, [w:] Pedagogika rewalidacyjna, red. A. Hulek, PWN, Warszawa 1980, s. $462-478$. 
zeszytu uwag), techniki socjometrycznej (np. jego pozycji w klasie), różnego rodzaju testów itp. W praktyce struktura ta jedynie pozornie sprzyja przejrzystości, ponieważ wymusza wielokrotne powracanie do zagadnień już spostrzeżonych, ponadto warunkuje sztuczną strukturyzację pól badawczych. Trudno jednak zaprzeczyć, że jest to strategia, w której łatwo określić ramy poszczególnych etapów badania.

Wariancją tej koncepcji studium (zbierania i opisu danych) jest deskrypcja przypadku uporządkowana dystansem informatorów do badanego obiektu, w założeniach warunkującym perspektywę poznania, np. wewnątrz (uczestników) i zewnątrz (obserwatorów) dziania się procesów szkolnych. Naturalnie dystans informatorów może zostać wyznaczony innymi możliwymi rozróżnieniami, np. ulokowanymi w Bronfenbrennerowskim podziale środowiska na mikrosystem, mezosystem, egzosystem, makrosystem. Ten ostatni przykład wymaga określenia granic systemów w aspekcie relacji z obiektem badań - w odniesieniu do ucznia z lekką niepełnosprawnością realizującego obowiązek szkolny w placówce ogólnodostępnej takiego rozgraniczenia $\mathrm{w}$ procesie analizy danych dokonała m.in. Anna Zamkowska ${ }^{39}$.

To przykłady struktury opisu wyprowadzony z metod poznania oraz związanych $\mathrm{z}$ nimi technik gromadzenia informacji, zatem warunkowany jest założeniami epistemologicznymi.

Kolejna możliwa struktura studium szczególnie osadzona w zakresie opisu danych oraz ich interpretowania może zostać uporządkowana przy pomocy kolejności sformułowanych problemów badawczych. To także jedna z możliwych, stosunkowo nieskomplikowanych i przejrzystych kompozycji. Umożliwia, pod warunkiem przemyślanej konstrukcji problematyki badawczej, kolejne systematyczne rozpatrywanie określonych pól badawczych. Mogą one być zbieżne z wykorzystanymi technikami zbierania danych. Z taką

${ }^{39}$ A. Zamkowska, Wsparcie edukacyjne uczniów z upośledzeniem umysłowym w stopniu lekkim w różnych formach kształcenia na I etapie edukacji, Wydawnictwo Politechniki Radomskiej, Radom 2009. 
sytuacją mamy do czynienia, kiedy na określone pytanie badawcze szukamy odpowiedzi przy pomocy jednej techniki badawczej. Zwykle jednak problem badawczy odzwierciedlony w pytaniu wymaga zastosowania kilku narzędzi i technik badawczych w celu zebrania danych stanowiących quantum informacji do udzielania odpowiedzi opisowej. Konstrukcja ta, szczególnie w dojrzałych badaniach, pozostaje w ścisłym związku z teoriami, z których zostały wyprowadzone problemy badawcze. Może też być odzwierciedleniem problematyki ulokowanej w praktyce codziennej. Wariancją tej konstrukcji będzie wykorzystanie założeń teorii ugruntowanej w studium przypadku, czyli przyjęcie schematu badań, w którym badacz generuje problemy ze zbioru zebranych już danych. Wówczas kierują one zainteresowanie badacza na kolejne pola eksploracji. Jest to przykład koncepcji porządkowanej - nieco upraszczając założeniami metodologicznymi.

Konsekwentnie nawiązując do studium osoby z niepełnosprawnością, przykładem opisanej konstrukcji jest zbiór problemów w związku z funkcjonowaniem w określonych rolach społecznych, np. członka rodziny, pracownika, członka społeczności lokalnej, członka organizacji społecznej, sąsiada itp. Struktura ta umożliwia holistyczny obraz funkcjonowania społecznego $\mathrm{w}$ relacji z obiektami stanowiącymi kontekst codzienności badanej osoby. Koncepcja takiej problematyki badawczej może zostać skrzyżowana z pytaniem o warunki nakładania się na te role - roli osoby niepełnosprawnej versus pełnosprawnej. To zaś pozwala skoncentrować się na tym co unikatowe (w aspekcie inności) oraz tym co wspólne i przeciętne w obszarze badanego przypadku i zrozumieć istotę niepełnosprawności również (a może szczególnie) jako konstruktu społecznego.

\section{Zakończenie}

Studium przypadku jest metodą często wykorzystywaną w różnych dyscyplinach naukowych. O jej zastosowaniu decydują nie tyle pobudki metodologiczne (studium może być osadzone $\mathrm{w}$ pro- 
cedurach jakościowych, ilościowych oraz mieszanych), co przede wszystkim zainteresowanie konkretnym przypadkiem. Jako forma badania, studium przypadku definiowane jest więc przez zainteresowanie konkretnym zjawiskiem, a nie przez zastosowanie określonych metod gromadzenia danych ${ }^{40}$. Uwaga badacza jest jednak ukierunkowana jego nastawieniem na konkretny zakres problemów. Może on być warunkowany eksplorowaniem tego co oryginalne, jak i tym co przeciętne. Studia nad niepełnosprawnością (także te osadzone w pedagogice specjalnej) skierowane są zwykle na dostrzeganie unikatowości jakie niosą ze sobą ograniczenia oraz społecznie nakładane na nie utrudnienia, to zaś gloryfikuje indywidualność. Neofityzm indywidualności nie może jednak przesłonić przeciętności, która wyznacza codzienność wielu obszarów funkcjonowania osób z niepełnosprawnością. Racjonalnie skonstruowana koncepcja studium przypadku osoby $\mathrm{z}$ niepełnosprawnością pozwala na poznanie i zrozumienie wzajemnych relacji tego co unikatowe i przeciętne w jej życiu, umożliwia także szczególny - co starałem się przedstawić w artykule - wielowymiarowy rozwój badacza jako fachowca oraz jako osoby.

\section{Bibliografia}

Baranowicz K., Studium indywidualnego przypadku w pracy pedagoga specjalnego, [w:] Pedagogika specjalna w reformowanym ustroju edukacyjnym, red. Z. Palak, UMCS, Lublin 2001.

Bruner J., Kultura edukacji, Universitas, Kraków 2006.

Dudzikowa M., Pomyśl siebie. Minieseje dla wychowawców klasy, GWP, Gdańsk 2007.

Feyerabend P., Jak być dobrym empirystą, PWN, Warszawa 1979.

Flyvbjerg B., Pięć mitów o badaniach typu studium przypadki, "Studia Socjologiczne" 2005, nr 2.

Hocutt A.M., Fowler K.M., Case Study Research: An Overview, [w:] Qualitative Research Methods in Special Education, red. J. Paul, J. Kleinhammer-Tramill, K. Fowler, Love Publishing Company, Denver - London - Sydney 2009.

40 R.E. Stake, op. cit., s. 623. 
Hulek A., Wspólne $i$ swoiste zagadnienia w rewalidacji różnych grup osób z odchyleniami od normy, [w:] Pedagogika rewalidacyjna, red. A. Hule, PWN, Warszawa 1980.

Janion M., Niesamowita Stowiańszczyzna, Wydawnictwo Literackie, Kraków 2006.

Konarzewski K., Jak uprawiać badania oświatowe. Metodologia praktyczna, WSiP, Warszawa 2000.

Konecki K., Studia z metodologii badań jakościowych. Teoria ugruntowana, Wydawnictwo Naukowe PWN, Warszawa 2000.

Kubinowski D., Jakościowe badania pedagogiczne. Filozofia - metodyka - ewaluacja, UMCS, Lublin 2010.

Łobocki M., Wprowadzenie do metodologii badań pedagogicznych, Impuls, Kraków 1999.

Obłój K., Wąsowska A., Studium przypadku, [w:] Metody badawcze w zarzadzaniu humanistycznym, red. M. Kostera, Wydawnictwo Akademickie Sedno, Warszawa 2015.

Okoń W., Wprowadzenie do dydaktyki ogólnej, Wydawnictwo Żak, Warszawa 1995.

Pawłowska B., Studium przypadku, [w:] Stownik socjologii jakościowej, red. K. Konecki, P. Chomczyński, Difin, Warszawa 2012.

Pilch T., Bauman T., Zasady badań pedagogicznych. Strategie ilościowe i jakościowe, Żak, Warszawa 1998.

Rubacha K., Metodologia badań nad edukacja, Wydawnictwo Akademickie i Profesjonalne, Warszawa 2008.

Stake R.E., Jakościowe studium przypadku, [w:] Metody badań jakościowych, t. 2, red. N.K. Denzin, Y.S. Lincoln, Wydawnictwo Naukowe PWN, Warszawa 2009.

Strumińska-Kutra M., Koładkiewicz I., Studium przypadku, [w:] Badania jakościowe. Metody i narzędzia, t. 2, red. D. Jemielniak, Wydawnictwo Naukowe PWN, Warszawa 2012.

Szczepański J., Sprawy ludzkie, Czytelnik, Warszawa 1980.

Szczepański J., O indywidualności, Instytut Wydawniczy Związków Zawodowych, Warszawa 1988.

Yin R.K., Studium przypadku w badaniach naukowych. Projektowanie $i$ metody, Wydawnictwo Uniwersytetu Jagiellońskiego, Kraków 2015.

Zamkowska A., Wsparcie edukacyjne uczniów z upośledzeniem umysłowym w stopniu lekkim w różnych formach kształcenia na I etapie edukacji, Wydawnictwo Politechniki Radomskiej, Radom 2009. 